\title{
Strategi Pemasaran Sepeda Motor Merek Honda Tipe Matic (Studi Kasus PT. HOHO Pekanbaru)
}

\author{
Nia Anggraini SE., M.Si ${ }^{1}$ \\ Sekolah Tinggi Ilmu Ekonomi Persada Bunda \\ anggraininia87@yahoo.com ${ }^{1}$
}

\begin{abstract}
Abstrak
Penelitian dilakukan di Kota Pekanbaru, tujuannya adalah mengetahui kebijakan yang harus dilakukan perusahaan dalam meningkatkan pemasaran sepeda motor merek "Honda" tipe matic khususnya beat pada PT. HOHO Pekanbaru. Hasil penelitian ini sebagai bahan informasi bagi pembaca dan bahan acuan bagi peneliti lainnya tentang masalah strategi pemasaran, serta sebagai pengembangan masa depan perusahaan penyalur sepeda motor merek "Honda".

Metode analisa data dalam penelitian ini adalah analisa deskriptif, yaitu suatu metode penelitian yang menggambarkan suatu gejala dan peristiwa pada masalah aktual atau mencari fakta dengan interpretasi tepat sebagaimana adanya, dan tidak digunakan sebagai pembuat kesimpulan lebih luas.

Dari hasil penelitian diperoleh bahwa PT. HOHO Pekanbaru telah berhasil mendistribusikan produknya berupa sepeda motor merek "Honda: beat tipe matic dari segi kelengkapan fungsi (fitur), desain, pilihan warna, keunggulan, dan daya tahan sangat unggul dan lengkap, telah berhasil menetapkan harga sesuai dengan kebutuhan konsumen dalam persaingan dan biaya kemudian telah melakukan promosi produk dengan baik, seperti advertising, sales promotion, ataupun personal selling. PT. HOHO Pekanbaru juga dinilai sudah mampu bersaing secara sangat baik dari segi persaingan merek jika dibandingkan dengan merek sepeda motor lainnya.
\end{abstract}

Kata kunci: Produk, Harga, Promosi, Persaingan

\section{Pendahuluan}

Dari hasil pengamatan secara langsung di lapangan, keberadaan sepeda motor yang semakin banyak melalui jalan-jalan di Kota Pekanbaru menandakan bahwa kebutuhan masyarakat akan sepeda motor terus mengalami peningkatan dan ini membawa dampak bagi perusahaan yang menyalurkan atau memasarkan sepeda motor. Dalam melakukan pemasaran, perusahaan penyalur sepeda motor dapat berperan dalam mempengaruhi pembeli agar menjatuhkan pilihannya terhadap suatu produk yang mereka tawarkan. Walaupun barang yang dipasarkan telah diterima konsumen, namun perusahaan harus dapat menghadapi masalah persaingan dengan perusahaan lain yang memproduksi barang sejenis untuk menetapkan kebijaksanaan pemasaran dengan menganalisa situasi dan kondisi pemasaran produk yang dihasilkan, sehingga dapat mendorong meningkatnya permintaan dan memperoleh keuntungan yang maksimal.

Jika suatu perusahaan melakukan pemasaran dan menguasai pangsa pasar produknya yang cukup besar, maka perusahaan dapat menarik minat konsumen untuk membeli dan mengkonsumsi produk tersebut. Meningkatknya kebutuhan sepeda motor berdampak terhadap pertumbuhan dan perkembangan dunia usaha dibidang industri kendaraan sepeda motor. Hal ini mengakibatkan persaingan industri sepeda motor dalam memproduksi produknya dengan memproduksi berbagai tipe dan merek sepeda motor yang berbeda-beda, adapun produk jenis tersebut telah menyebabkan persaingan kuat dalam merebut pangsa pasar antara para penyalur/dealer sepeda

${ }^{1}$ Korespondensi: Nia Anggraini SE., M.Si. Sekolah Tinggi Ilmu Ekonomi Persada Bunda. Jl. Diponegoro No.42 Pekanbaru - Riau. Telepon. 0761-40218 E-mail. anggraininia87@yahoo.com 
motor. Hal seperti ini terjadi pada PT. HOHO Pekanbaru sebagai distributor/dealer sepeda motor merek Honda. Dimana penjualan terhadap sepeda motor tipe matic khususnya Honda beat penjualannya sangat tinggi di tiga tahun terakhir. Hasil wawancara dengan manajer perusahaan PT. HOHO mengatakan bahwa penjualan Honda beat hampir setiap satu bulannya bisa mencapai 100-300 unit sepeda motor "Honda" beat yang terjual.

Dalam memasarkan produknya PT. HOHO bersaing dengan dealer sepeda motor lain yang menjual tipe yang sama (matic) yaitu merek Yamaha dan Suzuki. PT. HOHO Pekanbaru merupakan salah satu penyalur resmi sepeda motor "Honda" di Pekanbaru yang menjual sepeda motor berbagai tipe diantaranya Sepeda Motor tipe Matic khususnya honda Beat. Wawancara peneliti dengan bagian pemasaran PT. HOHO tingginya permintaan sepeda motor merek "Honda" tipe matic khususnya Honda beat di Pekanbaru menyebabkan pemasaran sepeda motor di PT. HOHO Marpoyan menjadi meningkat.

\section{Literature Review/Related Works}

Kotler dan Keller (2012:6) "Pemasaran adalah merupakan proses sosial baik oleh individu maupun kelompok dalam memperoleh apa yang mereka inginkan dan butuhkan melalui penciptaan".

Dalam pengertian lainnya Assauri (2011:5) dikatakan bahwa "Pemasaran sebagai usaha untuk menyediakan dan menyampaikan barang dan jasa yang tepat kepada orang-orang yang tepat pada tempat dan waktu serta harga yang tepat dengan promosi dan komunikasi yang tepat". Menurut Alma (2013:5) "Pemasaran adalah proses dimana seseorang atau kelompok dapat memenuhi need dan want melalui penciptaan, penawaran dan pertukaran barang dan jasa".

\section{Produk}

Mursid (2008:71) mengatakan bahwa "Produk adalah sebagai hasil akhir yang mengandung elemen-elemen fisik, jasa dan hal-hal yang simbolis yang dibuat dan dijual oleh perusahaan untuk memberikan kepuasan dan keuntungan bagi pembelinya".

Basu Swastha dan Irawan (2008:135) mengemukakan "Produk adalah suatu sifat yang kompleks baik dapat diraba, maupun tidak dapat diraba, termasuk bungkus, warna, harga, prestise perusahaan dan pengecer, pelayanan perusahaan dan pengecer yang diterima oleh pembeli untuk memuaskan keinginan dan kebutuhannya".

Menurut Kottler dan Keller (2012:4), "Produk adalah segala sesuatu yang dapat ditawarkan kepasar untuk memuaskan keinginan atau kebutuhan".

\section{Harga}

Kotler dan Armstrong (2013:151) "Harga adalah sejumlah uang yang dibebankan atas suatu barang atau jasa atau jumlah dari nilai uang yang ditukar konsumen atas manfaat-manfaat karena memiliki atau menggunakan produk atau jasa tersebut".

"Harga (price) adalah jumlah semua nilai yang diberikan oleh pelanggan untuk mendapatkan keuntungan dari memiliki atau menggunakan suatu produk atau jasa (Philip Kolter, 2008:345)".

Menurut (Swastha \& Irawan, 2008:241) harga adalah jumlah uang (ditambah beberapa produk kalau mungkin) yang dibutuhkan untuk mendapatkan sejumlah kombinasi dari produk dan pelayanannya.

\section{Promosi}

Menurut Gito Sudarmo (2008:237), "Promosi merupakan kegiatan yang ditujukan untuk mempengaruhi konsumen agar mereka dapat kenalan produk yang ditawarkan oleh 
perusahaan kepada mereka dan kemudian mereka menjadi senang lalu membeli produk tersebut".

"Promosi adalah komunikasi yang persuasif, mengajak, mendesak, membujuk, meyakinkan dan ciri dari komunikasi yang persuasif adalah ada komunikator yang secara terencana mengatur berita dan cara penyampaiannya untuk mendapatkan akibat tertentu dalam sikap dan tingkah laku sipenerima (target pendengar), cara promosi dibagi dalam advertising, personal selling, publisitas, sales promotion (Mursid,2008:95)”.

Dan menurut (Kotler dan Amstrong, 2013:51) "Promosi adalah aktivitas mengkomunikasikan produk dan membujuk pelanggan sasaran untuk membelinya".

\section{Persaingan}

(Griffin\&Ebert,2008:280) "Dalam lingkungan yang persaingannya sengit, tenaga pemasaran harus meyakinkan pembeli bahwa mereka harus membeli produk mereka, bukannya membeli produk yang dijual oleh penjual lain. Karena pembeli konsumen maupun pembeli komersial memiliki sumber daya yang terbatas yang harus dikeluarkan, setiap dolar yang dikeluarkan untuk membeli satu produk tidak lagi dapat digunakan untuk pembelian lain. Dengan demikian, setiap program pemasaran mencari cara agar produknya terlihat paling menarik. Secara teori, program yang gagal akan kehilangan rupiah untuk pembeli untuk selamanya (atau paling tidak sampai waktu keputusan pembelian berikutnya). Tenaga-tenaga pemasaran menentukan cara terbaik menempatkan produk-produk mereka sendiri untuk tiga tipe persaingan yaitu: Produk substitusi berbeda dari produk pesaing tetapi dapat mengisi kebutuhan yang sama; Persaingan merek terjadi antara produk-produk yang serupa; Persaingan internasional menyandingkan produk-produk pelaku pemasaran domestik terhadap pesaing asing”.

(Radiosunu, 2001:13) ada beberapa bentuk persaingan, antara lain persaingan umum yaitu persaingan yang berasal dari golongan produk lainnya dapat memenuhi kebutuhan yang sama dari konsumen; kemudian persaingan antara bentuk produk yaitu persaingan antara versi produk tertentu; dan persaingan antara perusahaan yaitu persaingan antara perusahaan-perusahaan yang menghasilkan barang/jasa sejenis.

"Di dalam industri, perusahaan harus mengetahui struktur biaya, politik harga, promosi dan beberapa aspek persaingan lain yang dapat mempengaruhi perencanaa serta operasinya (Swastha \& Irawan, 2008: 18)”.

\section{Metode Penelitian}

Populasi pada penelitian ini adalah semua konsumen yang membeli dan servis sepeda motor Honda matic beat di PT. HOHO Pekanbaru. Untuk itu sampel yang dipilih untuk mewakili populasi adalah sebanyak 100 orang konsumen sepeda motor "Honda" matic beat .

Jenis data dalam penelitian ini adalah data primer. Sumber data primer diperoleh dari responden yang dijadikan objek penelitian, yaitu konsumen sepeda motor "Honda" beat. Adapun data yang diperlukan adalah data tentang produk, harga, promosi, dan persaingan, serta data lainnya untuk keperluan penelitian.

Data primer didapat dengan cara wawancara terstruktur dan observasi. Wawancara terstruktur yaitu dengan mengadakan tanya jawab langsung kepada responden (pemilik sepeda motor honda beat) dengan membawa sederetan pertanyaan yang telah disusun terlebih dahulu. Sedangkan observasinya dilakukan dengan cara mengadakan pengamatan langsung ke objek penelitian dengan tujuan untuk memastikan bahwa informasi dan data yang diperoleh tersebut adalah benar.

\section{Metode Tulisan/Method}


Penulis menganalisa data menggunakan analisa deskriptif. Menurut Sugiyono (2017:147) "Analisa deskriptif adalah metode yang digunakan untuk menganalisis data dengan cara mendeskripsikan atau menggambarkan data yang telah terkumpul sebagaimana adanya tanpa bermaksud membuat kesimpulan yang berlaku untuk umum atau generalisasi”. Metode penelitian deskriptif ini bertujuan untuk mengumpulkan dan menganalisis data baik primer ataupun sekunder yang mempunyai hubungan erat dengan masalah yang diteliti kemudian diinterprestasikan secara deskriptif guna mendapatkan gambaran tentang masalah yang diteliti, kemudian membandingkannya dengan pengetahuan teoritis untuk meneruskan persoalan dan kemungkinan pemecahannya. Untuk memperoleh hasil yang diharapkan maka penulis melakukan penelitian untuk mendapatkan data serta teori yang dapat digunakan untuk mendukung analisa. Dalam metode deskriptif ini memaparkan situasi dan peristiwa.

\section{Hasil}

"Basu Swastha dan Irawan (2008:135) mengemukakan produk adalah suatu sifat yang kompleks baik dapat diraba, maupun tidak dapat diraba, termasuk bungkus, warna, harga, prestise perusahaan dan pengecer, pelayanan perusahaan dan pengecer yang diterima oleh pembeli untuk memuaskan keinginan dan kebutuhannya". Dan menurut Kottler dan Keller (2012:4), "Produk adalah segala sesuatu yang dapat ditawarkan kepasar untuk memuaskan keinginan atau kebutuhan".

Salah satu unsur terpenting dari strategi marketing mix adalah produk, karena produk perusahaan dapat mencapai tujuannya memperoleh keuntungan. Strategi produk memiliki tujuan agar tercapainya sasaran pasar yang meningkatkan kemampuan bersaing. Produk tidak saja dilihat dari bentuk fisiknya, tetapi juga mencakup pelayanan, harga, prestise, pabrik, dan penyalurannya yang semua itu diharapkan memenuhi kebutuhan dan keinginan konsumen.

Produsen produk sepeda motor merek "Honda" tipe matic telah mendesain produknya sedemikian rupa agar dapat diterima oleh konsumen. Produsen produk Honda matic khususnya beat selalu mengupayakan untuk dapat memberikan kepuasan kepada penggunanya, misalnya memformulasikan kembali strategi pemasaran dan tidak hanya kondisi ekonomi saja yang berubah tetapi pesaingnya juga memberikan serangan baru, namun bagi produk Honda beat itu melewati tahap baru, minat konsumen, dan persyaratan pembeli. Perusahaan dapat merencanakan strategi pengganti yang tepat disetiap tahap dalam siklus hidup produk tersebut. Perusahaan Honda selalu memperpanjang umur dan profitabilitas produk Honda beat tersebut walaupun tahu bahwa produk itu tidak akan bertahan selamanya, namun istilahnya kepuasan pemakaian konsumen tercapai dan kepercayaan konsumen untuk produk Honda beat tertanam secara individual. Maka dari itu, produk Honda beat harus diperhatikan sedemikian rupa agar dapat diterima konsumen sehingga konsumen loyal terhadap produk tersebut.

Ditinjau dari segi kelengkapan fungsi (fitur) dimana berdasarkan 65\% tanggapan responden menyatakan bahwa kelengkapan fungsi Fitur sepeda motor merek "Honda" tipe matic khususnya beat sangat lengkap, 25\% tanggapan responden menyatakan lengkap, dan $10 \%$ responden menyatakan tidak lengkap. Kemudian tentang desain kendaraan sepeda motor Honda matic beat juga ditanggapi dengan sangat bagus oleh responden dengan persentase tanggapan sebesar 60\%, $30 \%$ responden menanggapi dengan pernyataan bagus, sedangkan 10\% lainnya menanggapi tidak bagus. Pilihan warna sepeda motor Honda matic yang ditawarkan sangat bagus dengan persentase tanggapan responden sebesar 70\%, 25\% responden menyatakan bagus, dan hanya 5\% responden yang memberikan pernyataan tidak bagus. Begitu juga dengan keunggulan dan daya tahan serta kepuasan pemakaian terhadap sepeda motor "Honda" tipe matic beat ditanggapi responden dengan sangat puas dengan persentase sebesar $63 \%, 22 \%$ responden menanggapi puas, dan $15 \%$ responden menganggapi tidak puas. 
Menurut (Swastha \& Irawan, 2008:241) "Harga adalah jumlah uang yang dibutuhkan untuk mendapatkan sejumlah kombinasi dari produk dan pelayanannya. Harga merupakan faktor penentu bagi permintaan terhadap pasar produk yang mempengaruhi posisi persaingan, selain itu juga dapat mempengaruhi market share. berdasarkan hal tersebut produsen Honda beat dapat menentukan harga yang paling tepat dalam arti dapat memberikan keuntungan yang paling baik. Harga terbentuk dari kompetensi produk untuk memenuhi tujuan dua pihak, yaitu produsen dan konsumen. Produsen memandang harga sebagai nilai barang yang mampu memberikan manfaat pencapaian tujuan organisasi, sedangkan konsumen memandang harga sebagai nilai barang yang mampu memberikan manfaat atas pemenuhan kebutuhan dan keinginannya, dimana dapat dilihat dari kebijaksanaan harga yang ditetapkan dan kesesuaian harga dengan kualitas”.

Dalam melaksanakan kebijakan produk yang akan ditawarkan kepada konsumen dan agar konsumen merasa puas terhadap produk dan mutu barang, maka perusahaan Honda beat dapat menetapkan harga jual yang tepat. Hal ini karena kesalahan dalam penetapan harga jual dapat memperlambat hasil pemasaran maupun mendatangkan kerugian. Dengan demikian produsen Honda beat sangat berhati-hati dalam menentukan atau menetapkan harga produknya pada saat ada penawaran dari pembeli. Faktor-faktor yang mempengaruhi tingkat harga, yaitu biaya; persaingan; harga; pengawasan pemerintahan; keadaan perekonomian; elastisitas permintaan; penawaran dan permintaan.

Interaksi yang terjadi antara harga dan kuantitas disebut dengan hukum permintaan yang semakin menurun (low of diminishing demand) dengan syarat adalah jika harga barang naik, jumlah yang diminta akan semakin kecil, sebaliknya jika harga barang diturunkan maka jumlah yang diminta akan semakin besar. Bahwa harga sepeda motor merek "Honda" tipe matic khususnya beat terhadap persaingan harga adalah lebih terjangkau dari perusahaan lain dengan tipe sepeda motor matic juga, ini terlihat dari banyaknya jawaban responden terhadap pernyataan harga sepeda motor Honda tipe matic terjangkau dengan persentase sebesar $70 \%$.

Suatu produk akan digunakan jika telah diketahui oleh konsumen manfaatnya tersebut. Akan tetapi apabila produk tidak dikenal konsumen, maka produk tidak akan diketahui kegunaannya dan tidak akan dibeli oleh konsumen. Oleh sebab itu perusahaan Honda khususnya tipe matic beat berupaya untuk selalu memperkenalkan produknya kepada konsumen agar dapat menciptakan peningkatan permintaan atas produk tersebut. Usaha tersebut dilakukan dengan promosi.

Promosi adalah cara penyampaian informasi kepada calon konsumen yang akan membeli produk yang kita tawarkan. Sehubungan dengan kendaraan sepeda motor merek "Honda" tipe matic khususnya beat, kebijakan promosi ditetapkan dari produsen. Sedangkan PT. HOHO Pekanbaru hanya melakukan promosi perusahaan yang tidak signifikan terhadap suatu tipe merek produknya, melainkan bersifat umum terhadap seluruh tipe merek yang dipasarkan diperusahaan ini. Promosi yang dilakukan perusahaan dengan memperhatikan besarnya dana yang dianggarkan untuk promosi, sehingga apabila ingin mempromosikan suatu tipe merek saja akan membutuhkan biaya promosi yang cukup besar. Selain itu alasan lain untuk sulitnya dilakukan promosi adalah sifat pasar yang luas secara geografis, konsentrasi pasar dan berbagai macam sifat pembeli.

Dalam melakukan kegiatan promosi ada beberapa macam cara dilakukan PT. HOHO Pekanbaru diantaranya promosi dengan advertising/periklanan, Sales Promotion dan Personal Selling. Advertising/ periklanan dilakukan di media cetak, televisi dan radio. Sales Promotion dilakukan pada suatu even yang dinilai pengunjungnya membutuhkan suatu alat komunikasi berupa kendaraan sepeda motor. Dan Personal Selling dilakukan dengan pemberian pelayanan. Perusahaan melakukan berbagai macam cara untuk menjaga hubungan baik dengan para perantara, perusahaan menawarkan tunjangan pembelian yaitu dengan tawaran potongan harga pada setiap pembelian selama jangka waktu tertentu. 
Lebih dari $50 \%$ responden menanggapi sangat baik tentang promosi oleh pihak PT. HOHO Pekanbaru baik dengan cara advertising/periklanan, Sales Promotion dan Personal Selling.

Persaingan tidak pernah mendapatkan penghargaan yang layak sebab banyak orang melihat persaingan dari segi yang merusak dibandingkan dari segi baiknya. Dengan adanya persaingan dapat mencegah ketidakacuhan sehingga menimbulkan orang-orang yang tangguh. Pada saat ini persaingan antara perusahaan dealer sepeda motor semakin kuat dan meningkat. Hal ini dikarenakan dari semakin banyaknya perusahaan yang mengeluarkan produk sepeda motor tipe sejenis (matic) dan memperebutkan konsumen yang sama pula. Untuk itu setiap perusahaan harus bersaing dengan perusahaan lain agar kelangsungan hidup perusahaan tetap terjaga. Persaingan bagi suatu perusahaan dapat pula ditentukan dengan menitikberatkan pada tingkat persaingan harga atau bukan harga sehingga dengan strategi yang dimiliki dan kebijaksanaan pemasaran yang baik maka perusahaan mampu untuk bersaing dan bisa meningkatkan volume pemasaran. Persaingan yang terjadi pada pemasaran sepeda motor merek "Honda" tipe matic khususnya Honda beat pada PT. HOHO Pekanbaru adalah persaingan merek dan persaingan model/bentuk. Dari hasil kesimpulan tanggapan responden bahwa persaingan terhadap merek sepeda motor merek "Honda" tipe matic (Beat) sangat baik jika dibandingkan dengan kendaraan sepeda motor matic merek lainnya dengan tanggapan responden sebesar 52\%. Selanjutnya persaingan terhadap bentuk sepeda motor Honda matic (beat) ditanggapi responden dengan sangat baik juga sebesar $60 \%$ responden. Artinya Honda beat sudah melekat dipikiran konsumen adalah sepeda motor yang terbaik dengan bentuk yang tidak akan ketinggalan zaman walaupun telah dipakai bertahun-tahun atau dapat dikatanya model Honda beat sepanjang zaman sehingga kepuasan pemakaian konsumen tercapai.

\section{Simpulan}

Dari hasil penelitian ini, ada beberapa kesimpulan yang di dapat, diantaranya adalah:

PT. HOHO Pekanbaru merancang dan menghasilkan produknya berupa sepeda motor Honda tipe Matic beat dari segi kelengkapan fungsi (fitur), desain, pilihan warna, keunggulan, dan daya tahan sangat lengkap dan unggul dan berhasil menetapkan harga sesuai dengan kebutuhan konsumen dalam persaingan dan biaya yaitu harga, pengaruh harga, dan keterjangkauan harga. Kemudian telah melakukan promosi produk dengan baik, seperti advertising, sales promotion, ataupun personal selling. PT. HOHO juga dinilai sudah mampu bersaing secara sangat baik dari segi persaingan merek jika dibandingkan dengan merek sepeda motor lainnya. Dan dalam hal persaingan bentuk juga sudah mampu bersaing secara baik karena Honda beat bentuknya lebih sederhana dan bagus.

Beberapa saran yang dapat diberikan, adalah sebagai berikut:

Agar dimasa mendatang perusahaan produsen sepeda motor "Honda" Beat lebih meningkatkan lagi produknya sehingga dapat menjaga kepercayaan konsumen terhadap produk tersebut dan PT. HOHO Pekanbaru harus tetap mengontrol kebijakan harga dan kesesuaian harga dengan kualitas sehingga dapat menciptakan harga yang kompetitif jika dibandingkan dengan merek dari perusahaan lain yang menjual produk sepeda motor matic juga. Kegiatan promosinya ditingkatkan lagi seperti membujuk, merayu, dan meyakinkan konsumen membeli produk dan diharapkan kiranya perusahaan produsen dan pihak perusahaan distributor/dealer melakukan kerja sama dalam hal promosi serta mencari peluang lain dalam hal memperkenalkan sepeda motor merek "Honda" tipe matic hususnya beat di Pekanbaru serta sales promotion yang lebih menarik lagi sehingga konsumen merasa membutuhkan dan menginginkan produk sepeda motor tersebut 


\section{Daftar Pustaka}

Agnes Ulus, Algrina, "Bauran Pemasaran Pengaruhnya Terhadap Keputusan Pembelian Mobil

Daihatsu Pada Pt. Astra Internasional Manado", Jurnal Emba Vol.1 No.4 Desember 2013, Hal. 1134-1144, ISSN : 2303-1174.

Alma,Buchari, 2013, Manajemen Pemasaran dan Pemasaran Jasa, Bandung, Alfabeta.

Assauri,Sofyan, 2011, Manajemen Pemasaran Dasar, Konsep, dan Strategi, Jakarta, PT. Raja Grafindo Persada.

Ciptono,Fandy, Teguh Budiarto, 2012, Pemasaran Internasional Edisi Pertama, Fakultas Ekonomi, UGM.

Gitosudarmo, Indriyo, 2008, Manajemen Pemasaran, Edisi 1, Cetakan 4 Yogyakarta,UGM.

Griffin,Ricky W \& Ebert,Ronald J, 2008, Bisnis, Edisi ke Delapan Jilid 2, Erlangga.

Kotler,Philip, 2008, Manajemen Pemasaran, Edisi ke 12, Jilid 1, Indonesia, PT. Macanan Jaya Cemerlang.

Kotler,Philip \& Keller Kevin L, 2012, Manajemen Pemasaran, Edisi 13, Jilid 5, Jakarta, Erlangga.

Kotler,Philip, Armstrong, 2013, Prinsip-prinsip Pemasaran , Edisi 13, Jilid 1, Jakarta, Erlangga.

Mursid,M, 2008, Manajemen Pemasaran, Jakarta, PT. Bumi Aksara.

Panglaykim,J, 2011, Prinsip-Prinsip Kemajuan Ekonomi, Jakarta, PT. Kompas Media Nusantara.

Radiosunu, 2001, Manajemen Pemasaran Suatu Pendekatan Analisis, Edisi 2, Yogyakarta, Fakultas Ekonomi, UGM

Sugiyono, 2017, Metode Penelitian Kuantitatif, Kualitatif, dan R\&D. Bandung: Alfabeta

Swasta,Basu, 2001, Manajemen Penjualan, Edisi ke 3, Yogyakarta, Liberty.

Swasta,Basu, 2002, Azaz-Azaz Marketing, Edisi 3, Yogyakarta, Liberty.

Swasta,Basu,Irawan, 2012, Manajemen Pemasaran Modern, Yogyakarta, Liberty.

Swasta,Basu, 2008, Manajemen Pemasaran Modern, Yogyakarta, Liberty.

Tambajong, Geraldy,"Bauran Pemasaran Pengaruhnya Terhadap Penjualan Sepeda Motor Yamaha Di Pt. Sarana Niaga Megah Kerta Manado", Jurnal Emba 1291 Vol.1 No.3 September 2013, Hal. 1291-1301, ISSN: 2303-1174.

Umar,Husein, 2005, Riset Pemasaran dan Perilaku Konsumen, Jakarta, PT. Gramedia Pustaka Pertama.

Umar,Husein, 2003, Business An Introduction, Cetakan Kedua, Jakarta, PT. Gramedia Pustaka Utama. 